\title{
CARACTERIZACIÓN DE LOS POBRES EN LA LITERATURA PAREMIOLÓGICA ANDALUSÍ
}

\author{
ANA María CARBALleira \\ IEGPS (CSIC-Xunta de Galicia), Santiago de Compostela
}

\begin{abstract}
El objetivo de este artículo es contribuir a un conocimiento más exhaustivo de la historia socio-económica de al-Andalus en general y del tema de la pobreza involuntaria en particular. La literatura paremiológica andalusí proporciona un caudal de información nada desdeñable en relación con los diferentes aspectos relativos al tema en cuestión, tales como la concepción de la pobreza, sus causas y consecuencias, así como las distintas formas de contrarrestarla por parte de los afectados y del prójimo. El refranero andalusí pone a nuestra disposición una serie de imágenes establecidas con respecto a los pobres y a su estado, permitiéndonos conocer los estímulos que esta realidad social provocaba entre la población. Desde este punto de vista, este tipo de documentación permite apreciar las prácticas sociales existentes en al-Andalus, las cuales dejan traslucir los valores morales y éticos de esta sociedad.
\end{abstract}

Palabras clave. Pobreza; refranes; imágenes del pobre; al-Andalus
The aim of this article is to contribute to a more comprehensive knowledge of the socio-economical history of al-Andalus and particularly the topic of involuntary poverty. Andalusian proverbial literature provides a wealth of information concerning different aspects of this topic, such as the conception of poverty, its causes and consequences, and the different ways of offsetting it on the part of the affected and their neighbors. The Andalusian proverb collections offer a series of established images of the poor and their situation, which allows us to understand the effects that this social reality was provoking among the population. From this point of view, this type of documentation advances our knowledge about the social practices in al-Andalus, which suggest the moral and ethical values of this society.

Keywords: Poverty; proverbs; images of the poor; al-Andalus

\section{Introducción}

La existencia de un considerable número de colecciones paremiológicas árabes refleja la especial predilección de esta sociedad por las expresiones proverbiales. El término árabe acuñado para designar al refrán es matal y su plural amtāal («comparación»). Esta expresión tiene un significado más amplio que nuestro refrán, puesto que abarca una gran variedad de conceptos (máximas, sentencias, apotegmas, adagios, aforismos... ${ }^{1}$. Ya en los primeros tiempos del Islam, era fre-

${ }^{1}$ Sellheim, R., "Mathal", $E I^{2}$, VI, 806. 
cuente recurrir a $a m \underline{t} \bar{a} l$, versículos coránicos (tomados como proverbios) y dichos del Profeta ${ }^{2}$. El interés de los árabes por la recopilación de refranes como medio de salvaguardar la cultura oral de sus antepasados comienza en época omeya y continúa en la 'abbāsí ${ }^{3}$. En cierto modo, esta tendencia sigue vigente en la actualidad mediante las labores sistemáticas de edición y traducción de las colecciones paremiológicas existentes. Aunque estas circunstancias han facilitado enormemente el acceso a este tipo de literatura, la mayoría de los estudios emprendidos a partir de esta base documental se ha centrado en el ámbito filológico, recurriendo al análisis lingüístico e, incluso, estilístico de las fórmulas proverbiales ${ }^{4}$. Por el contrario, es preciso destacar el escaso uso que en el campo del arabismo se ha hecho de la literatura paremiológica como fuente de tipo social, al revés de lo que sucede en otros ámbitos, como el europeo, donde el interés por este tipo de estudios cuenta ya con una cierta tradición ${ }^{5}$.

Pero, ¿cuál es el valor real de la literatura paremiológica como fuente documental para la historia social de al-Andalus?

El refrán representa una situación arquetípica y se inserta en el discurso para aportar un argumento. En general, este tipo de expresiones está dotado de un buen sentido práctico, puesto que se revela como el enunciado estereotipado de una enseñanza de carácter moral y didáctico, extraída de la experiencia, mediante el cual se expresa una constata-

2 Al-Saidi, D., Proverbes arabes et français: étude comparée de thèmes et de structure, Tesis Doctoral, Universidad de Aix-en-Provence, 1980, 11. Respecto a los amtāa contenidos en el Corán y en el haditt, cfr. Sellheim, "Mathal", $E I^{2}, 811$; Gálvez, E., "Los "amtāal" en el Corán", Homenaje al Profesor José María Fórneas Besteiro, II, Granada, 1995, 1187-1197; Ibn Qayyim al-Ŷawziyya, Al-Amțāl fì l-Qur'ān al-karīm, Beirut, 1983.

3 Sobre colecciones árabes de refranes, cfr. Sellheim, "Mathal", $E I^{2}, 811-815$.

${ }^{4}$ Véase a título ilustrativo, García Gómez, E., "Paremiología y filología: Sobre “zahar" y “zahareño"”, Al-Andalus, 42 (1977), 391-408; idem, "Un poema paremiológico de Hilli, s. XIV, en "Kān wa-kān": con unas observaciones sobre esta forma poética", Al-Andalus, 36 (1971), 329-372; Ould Mohamed Baba, A. S., Estudio dialectológico y lexicológico del refranero andalusí de Abu Yahyà al-Zajjali, Zaragoza, 1999.

${ }^{5}$ Entre los trabajos más recientes que adoptan una perspectiva social, cfr. Lachiri, N., “Andalusi Proverbs on Women", Marín, M. y Deguilhem, R. (eds.), Writing the Feminine: Women in Arab Sources, Londres-Nueva York, 2002, 41-48; Sersen, W. J., "Stereotypes and attitudes towards slaves in Arabic proverbs", Willis, J. R. (ed.), Slaves and slavery in Muslim Africa, I, Londres, 1985, 92-105; Shirtiel, A., "Customs, manners and beliefs as reflected by some Arabic proverbs and idioms", The Arabist, 18 (1996), 113-121. Sobre este aspecto aplicado al ámbito europeo, véase la bibliografía contenida en Schulze-Busacker, E., Proverbes et expressions proverbiales dans la littérature narrative du Moyen-Âge français: recueil et analyse, París, 1985.

Al-Qanțara (AQ) XXVII 1, enero-junio 2006, pp. 105-135 ISSN 0211-3589 
ción o una regla de conducta, un consejo o una advertencia. Al tratarse de una cita heredada de la tradición, el argumento proporcionado por el proverbio está dotado de una gran autoridad ${ }^{6}$. Asimismo, la función argumentativa del refrán suele estar reforzada por su valor estético. La forma externa de los amtāl suele estar condicionada por una serie de particularidades lingüísticas, estilísticas y métricas, que contribuyen a enriquecer la expresión y a reforzar su fuerza argumentativa ${ }^{7}$.

El proverbio se presenta como un enunciado autónomo, con una estructura lingüística y semántica completa, caracterizado por la concisión y la brevedad. Si bien un refrán aislado no dice gran cosa, el conjunto de este tipo de expresiones permite construir un discurso dialéctico, a partir del cual se puede llegar a conocer el ambiente social, económico y cultural de un pueblo. Efectivamente, los proverbios nos ofrecen la imagen de la sociedad que los ha forjado, pues contienen informaciones relativas a situaciones de diversa índole que todo ser humano es susceptible de encontrar en el curso de su existencia. Mediante la observación del mundo, el individuo abstrae las normas del comportamiento humano y el refrán se convierte en un vehículo para plasmar esa descripción o recreación de la realidad. De un modo u otro, todas las formas paremiológicas tratan del individuo y de sus relaciones con la sociedad. Desde este punto de vista, las distintas observaciones, opiniones y sentimientos contenidos en los refranes se convierten en verdaderos juicios de valor ${ }^{8}$. De estos aspectos se infiere la importancia y la utilidad de los refranes para el estudio de la historia social de al-Andalus.

No obstante, las fuentes paremiológicas, suficientemente fidedignas para ser objeto de análisis social, presentan una serie de limitaciones que recomiendan adoptar una actitud prudente por parte del investigador. Por un lado, uno de los problemas que suscita este tipo de estudio es el relativo a la exhaustividad de las colecciones de refranes árabes efectuadas por los distintos compiladores. Asimismo, no debe

${ }^{6}$ Schapira, Ch., Les stéréotypes en français: proverbes et autres formules, Gap-París, $1999,88$.

7 Sellheim, "Mathal", $E I^{2}, 811$. Véase también Pellat, Ch., "Sur la formation de quelques expressions proverbiales en arabe", Arabica. Revue des Études Arabes, 23 (1976), $1-12$.

${ }^{8}$ Suard, F. y Buridant, C. (eds.), Richesse du proverbe: [communications présentées à Lille du 6 au 8 mars 1981, dans le cadre du Colloque de parémiologie], 2 vols., Lille, 1984, 1-3.

Al-Qanțara (AQ) XXVII 1, enero-junio 2006, pp. 105-135 ISSN 0211-3589 
descartarse la existencia de posibles alteraciones acaecidas en el registro por escrito de estas expresiones. Por otro lado, es preciso tomar en consideración los problemas de interpretación, ya que en algunos casos resulta harto difícil llegar a comprender el significado real de los refranes extraídos de su contexto social habitual. Inspirados en un acontecimiento histórico o forjados por las circunstancias de la vida cotidiana, los proverbios no siempre se comprenden fuera de su lugar de origen. Las dificultades se incrementan cuando los refranes han caído en desuso, como es el caso de los andalusíes, algunos de los cuales aluden a personajes, lugares o eventos, sobre los que no disponemos de información. A esto es preciso añadir los distintos significados que presentan las metáforas en las diferentes culturas. No deja de ser revelador que en el siglo VI/XII ya existiesen refranes no bien entendidos por los propios compiladores. Algunos, como al-Maydānī (m. 518/1124), proponían a veces una interpretación personal ${ }^{9}$. Por último, no se debe soslayar el inconveniente que plantea el hecho de que muchos refranes andalusíes deriven de modelos extranjeros. En efecto, algunos proverbios gozaban de una expansión geográfica muy amplia, dado el carácter universal de los conceptos que expresaban. Así, por ejemplo, los de Ibn 'Āṣim son refranes muy difundidos por todo el mundo islámico ${ }^{10}$. En este sentido, es preciso tener en cuenta que el refranero árabe oriental es el antecedente del andalusí, tanto desde el punto de vista de la cronología, como desde el punto de vista de la materia refranística ${ }^{11}$. Asimismo, los refranes árabes son hereditarios de una tradición más antigua, al haber recibido influencias de origen grecolatino, persa, hindú o extremo-oriental ${ }^{12}$.

9 A este respecto véase Abela, F. J. y Abela, S., Proverbes populaires du Liban Sud, París, 1981, XIII.

10 García Gómez, E., "Hacia un 'refranero' arábigo-andaluz. II: El refranero de Ibn 'Āsim en el ms. londinense", Al-Andalus, 35 (1970), 245. Sobre la interculturalidad del refrán en general, véase Sevilla Muñoz, J., Pocas palabras bastan: vida e interculturalidad del refrán, Salamanca, 2002.

${ }^{11}$ García Gómez, E., 'Hacia un 'refranero' arábigo-andaluz. V: Versión del libro sobre refranes de 'al-'Iqd al-Farīd' (siglo X). A) Preliminares y refranero de Aktam y Buzurŷmihr”, Al-Andalus, 37 (1972), 251-252. Así como el refranero andalusí procede del oriental, del mismo modo en el refranero español se encuentran algunos refranes de origen andalusí; cfr. García Gómez, "Una prueba de que el refranero árabe fue incorporado en traducción al refranero español", Al-Andalus, 42 (1977), 375-390.

12 Sellheim, "Mathal", $E I^{2}, 808-809$.

Al-Qanțara (AQ) XXVII 1, enero-junio 2006, pp. 105-135 ISSN 0211-3589 
Si bien las limitaciones inherentes a este tipo de material documental son insoslayables, no se puede negar que la literatura paremiológica constituya una documentación directa de valor inestimable para el conocimiento de la sociedad andalusí. Partiendo de esta premisa, voy a centrar mi atención en uno de los numerosos grupos sociales que son objeto de tratamiento en el refranero andalusí. Se trata del colectivo constituido por los pobres e indigentes. Desde este punto de vista, el objetivo principal de este artículo es contribuir a un conocimiento más exhaustivo de la historia socio-económica de al-Andalus en general y del tema de la pobreza en particular. Este estudio se enmarca en la línea de trabajos anteriores relativos al estado de pobres y necesitados en el seno de la sociedad andalusí con la finalidad de completar la visión parcial y fragmentaria ofrecida en ellos, recurriendo al empleo de nuevas fuentes documentales ${ }^{13}$. Sin lugar a dudas, el análisis del refranero andalusí añade nuevas perspectivas en este sentido, puesto que pone a disposición del investigador un caudal de información inestimable para un mejor conocimiento de los diferentes aspectos concernientes al tema en cuestión, tales como la concepción de la pobreza, sus causas y consecuencias, así como las distintas formas de contrarrestarla por parte de los afectados y del prójimo. Desde este punto de vista, el análisis de las actitudes de la población andalusí hacia los pobres involuntarios resulta fundamental para llegar a determinar cómo aparecen éstos caracterizados a través del refrán. Asimismo, este tipo de documentación permite apreciar las prácticas sociales existentes en al-Andalus, las cuales dejan traslucir los valores morales y éticos inherentes a esta sociedad. Finalmente, es preciso advertir que el tratamiento de determinados aspectos excedería los límites razonables de este trabajo. Por una parte, no se pretende abordar el análisis de la forma proverbial, ni tampoco responder a cuestiones relativas a circunstancias de índole lingüística, sino examinar el mensaje transmitido por el discurso proverbial, prestando especial atención a su función social. Por otra parte, tampoco se trata de

13 Me refiero a las siguientes publicaciones: Carballeira, A. M., Legados píos y fundaciones familiares en al-Andalus (siglos IV/X-VI/XII), Madrid, 2002; idem, "Pobres y caridad en al-Andalus", en Puente, C. de la (ed.), EOBA XIII (Identidades marginales), Madrid, 2003, 53-91; idem, "Pauvreté et fondations pieuses dans la Grenade nasride: aspects sociaux et juridiques", Arabica. Revue des Études Arabes, LII (2005), 391-416. Remito a la bibliografía contenida en estos trabajos en relación con esta cuestión aplicada a otras zonas del mundo islámico.

Al-Qanțara (AQ) XXVII 1, enero-junio 2006, pp. 105-135 ISSN 0211-3589 
emprender la evolución cronológica del refranero, sino que tan sólo se intentará precisar si los refranes empleados existen o no en otras colecciones andalusíes.

\section{Colecciones paremiológicas utilizadas}

El corpus del material utilizado en este trabajo consta de tres principales obras de referencia, todas ellas complementarias, por lo que el estudio de una conlleva el análisis de las otras. Me refiero a las compilaciones paremiológicas de al-Zaŷŷālī (m. 694/1294), Ibn 'Āṣim (m. 829/1426) y Alonso del Castillo (m. entre 1607 y 1610), cuya importancia estriba en el elevado número de refranes que contienen. Asimismo, no se ha descartado la consulta de otros refraneros de menor extensión, susceptibles de completar o matizar los datos aportados por los tres mencionados. En realidad, se trata de apartados de refranes incluidos por algunos autores en sus obras, como es el caso de Ibn 'Abd Rabbihi (m. 328/940), Ibn Hišām al-Lajmī (m. 577/1181-2) e Ibn Luyūn de Almería (m. 750/1349). A todas estas obras me referiré posteriormente de forma más pormenorizada.

Es bien sabido que la literatura culta y la popular no se producen en los mismos estratos sociales. La mayoría de las colecciones andalusíes pertenecen a refranes de origen popular (amtāal al- 'àmma), ya que éstos han sido recopilados en árabe dialectal andalusí, sin ser «trasladados» al árabe clásico por los autores cultos de las compilaciones paremiológicas. Por esta razón, estos proverbios populares reflejan más directamente el fondo social del cual emergen ${ }^{14}$. Si bien el discurso proverbial suele ser la marca de un modo de expresión no literario, el origen de los refranes andalusíes no siempre es vulgar. No se debe obviar que existen refranes procedentes de la poesía y la literatura clásicas. Así, por ejemplo, el proverbio erudito podía convertirse en popular, al correr entre las gentes, como es el caso de las expresiones contenidas en la obra de Ibn 'Abd Rabbihi. En otras ocasiones, el texto poético es el que deriva del refrán, como sucede con lo que

14 Al-Ahwānī, 'A. 'A., “Amt̄āl al-'āmma fī 1-Andalus", en Badawī, 'A. (ed.), Ilà Țāhà Husayn fì 'ìd mìlādi-hi al-sab 'in, El Cairo, 1962, 235-367. En lo que se refiere a la dicotomía existente entre élite social y clases populares en la sociedad islámica, cfr. Beg, M. A. J., "Al-Khāṣṣa wa 'l-‘āmma", $E I^{2}$, IV, 1098-1100.

Al-Qanțara (AQ) XXVII 1, enero-junio 2006, pp. 105-135 ISSN 0211-3589 
E. García Gómez ha dado en denominar «proverbio rimado». El que escribe «proverbios rimados», como Ibn Luyūn, lo que hace es encuadrar en metros poéticos refranes desde antiguo existentes, explicarlos, fundirlos, diluirlos, glosarlos e, incluso, matizarlos. Finalmente, no se debe soslayar la posibilidad de localizar el aglutinamiento de dos tendencias en un mismo refranero. Tal es el caso de la obra de Ibn Hišām, en la que no todos los refranes tienen origen poético y en algunos es el texto poético el que procede del refrán ${ }^{15}$.

El hecho de verter este tipo de expresiones a otra lengua plantea algunos inconvenientes, entre los que cabe destacar la dificultad de traducir un refrán sin que éste pierda parte de su belleza estilística y de su particularidad expresiva. Por esta razón, he recurrido a la traducción ya existente de los 150 refranes que conforman la base documental de este estudio, incluyendo sus variantes. A continuación y siguiendo un orden cronológico, efectúo una breve presentación de cada una de las fuentes consultadas en este trabajo, prestando especial atención a sus principales características.

El cordobés Ibn 'Abd Rabbihi (s. IV/X) es el primer autor andalusí que incluyó un capítulo de más de 200 refranes en su obra al-'Iqd al-farìd. Esta primacía en época tan temprana nos permite saber cuáles eran los refranes conocidos en al-Andalus a finales del siglo III/IX y comienzos del IV/X. El 'Iqd es la cima del período de integración y asimilación de las aportaciones orientales en al-Andalus que comprende los siglos II/VIII y III/IX. Por tanto, los proverbios que incluye son orientales, hecho que suscita interrogantes sobre si son refranes importados eruditamente y sin vida en al-Andalus. Pero el hecho de localizarlos en refraneros posteriores parece indicar justamente lo contrario, si bien no debe descartarse del todo la posibilidad de que se trate de una mera repetición textual ${ }^{16}$. En cualquier caso, me ha parecido significativo incluir esta obra en el corpus documental del presente estudio por el interés que ofrecen los datos en ella registrados en relación con el tema que aquí nos ocupa.

La colección paremiológica del sevillano Ibn Hišām al-Lajmī (s. VI/XII) consta de 112 refranes. Independientemente de su proce-

15 A fin de evitar caer en la redundancia, remito a la bibliografía oportuna que, en relación con cada una de estas obras, traigo a colación en las siguientes páginas.

16 Véase el citado artículo de García Gómez, "Hacia un 'refranero' arábigo-andaluz. V", 249-323.

Al-Qanțara (AQ) XXVII 1, enero-junio 2006, pp. 105-135 ISSN 0211-3589 
dencia literaria o paremiológica, en ellos el predominio del Oriente islámico es casi absoluto. Sin embargo, hallamos proverbios de Ibn Hišām, cada vez más vulgarizados y adaptados, en obras andalusíes posteriores, como las de al-Zaŷŷālī e Ibn 'Āṣim, con algunas variantes ${ }^{17}$.

El refranero del cordobés Abū Yahyà 'Ubayd Allāh al-Zaŷȳālī (s. VII/XIII) es la recopilación más extensa que ha llegado hasta nosotros con 2157 refranes. Este trabajo contiene información sobre al-Andalus y Marruecos, probablemente porque el autor comenzó su recopilación mientras vivía en al-Andalus y la completó durante su estancia en Marrakech ${ }^{18}$.

La obra de Ibn Luyūn (s. VIII/XIV), autor almeriense de época nazarí, contiene 714 versos, de los cuales E. García Gómez ha extraído sólo 60. Como ya se ha mencionado, en Ibn Luyūn tenemos la creación a conciencia de un nuevo género, el «proverbio rimado», a partir de refranes ya existentes. El tono del «proverbio rimado» es piadoso y conforme con la buena moral religiosa. Algunos glosan textos coránicos, otros glosan hadītes proféticos, algunos se aproximan a la máxima y otros son exhortaciones religiosas ${ }^{19}$.

La recopilación paremiológica del granadino Abū Bakr Muḥammad b. Muhammad al-Qaysī Ibn 'Āṣim (s. IX/XV) contiene más de 800 refranes. No obstante, los diversos manuscritos que se conservan de la obra de Ibn 'Āṣim presentan diferencias en la extensión del texto, debido a la distinta materia refranística contenida. Sólo coinciden algunos refranes y a veces la coincidencia no excluye variantes muy considerables ${ }^{20}$. Esta diferencia en los manuscritos del texto se refleja en las dos versiones que de esta obra existen en castellano y que han sido realizadas por E. García Gómez y M. Marugán. Por ello, es recomendable la utilización de ambos trabajos, dada su complementariedad. Varios de los refranes de Ibn 'Āṣim aparecen en otras colecciones anteriores, es-

17 García Gómez, E., "Hacia un "refranero" arábigo-andaluz. I: Los refranes de Ibn Hišām Lajmī”, Al-Andalus, 35 (1970), 1-68.

18 Bencherifa, M., Amțāl al- 'awwāmm fì l-Andalus li-Abì Yahyà al-Zaŷŷālī, 2 vols., Fez, 1975, así como el mencionado trabajo de Ould Mohamed Baba, Estudio dialectológico y lexicológico del refranero andalusí de Abü Yahyà al-Zajjali.

${ }_{19}$ García Gomez, E., "Hacia un 'refranero' arábigo-andaluz. IV: Los proverbios rimados de Ben Luyūn de Almería (1282-1349)", Al-Andalus, 37 (1972), 1-75.

${ }^{20} \mathrm{Ibn}$ 'Āșim, El refranero andalusí de Ibn 'Āṣim al-Garnạțī, estudio lingüístico, transcripción, traducción y glosario de M. Marugán, Madrid, 1994, 8; García Gómez, "El refranero de Ibn 'Āṣim en el ms. londinense", 241-314. 
pecialmente en la obra de al-Zaŷŷālī. En opinión de M. Bencherifa, Ibn 'Āṣim no llegó a conocer la compilación de al-Zaŷȳālī y la coincidencia de refranes entre ambos responde a que los andalusíes seguían usando esas expresiones en los siglos VIII/XIV-IX/XV ${ }^{21}$.

El refranero del morisco granadino Alonso del Castillo (ss. XVIXVII) está considerado como la última recopilación de proverbios andalusíes. Consta de 1600 refranes y ocupa un puesto intermedio entre el más rico de al-Zaŷŷālī y el menos de Ibn 'Āṣim, con los que suele coincidir, si bien con frecuentes variantes y con un singular aporte de refranes tardíos que se remontan a las postrimerías del reino nazarí o, incluso, del período de la dominación cristiana. Nos ofrece la posibilidad de observar la evolución de un mismo refrán desde su aparición en al-Zaŷŷālī y a través de Ibn 'Āṣim ${ }^{22}$.

\section{Análisis de los refranes}

\subsection{Concepción de los pobres y su estado}

La literatura paremiológica nos ilustra sobre el concepto de pobreza existente en el seno de la sociedad andalusí, así como sobre las distintas actitudes y reacciones que los pobres suscitaban entre sus coetáneos. Es preciso destacar el predominio de referencias a los pobres involuntarios en contraposición al extraordinario laconismo del refranero andalusí en todo lo concerniente a la privación voluntaria.

No obstante, el reducido número de noticias existentes en torno al ascetismo en al-Andalus no desmerece en absoluto la información que de ellas se puede extraer. De este modo, los refranes informan del mal concepto inherente a las prácticas ascéticas. En algunos casos, no pasan del todo desapercibidos los prejuicios que se ciernen sobre los ascetas, cuya amistad no era del todo recomendable: «Ni con el violento, ni con los ascetas» ${ }^{23}$, «Si ves en estos tiempos a alguien ascético, sélo tú (con él) más y más $[\ldots] \gg{ }^{24}$. Por el contrario, en otras oca-

${ }^{21}$ Bencherifa, Amțāl al-'awwāmm fì l-Andalus, I, 139-140.

22 Corriente, F. y Bouzineb, H., Recopilación de refranes andalusies de Alonso del Castillo, Zaragoza, 1994. Sobre este compilador, véase también Cabanelas, D., El morisco granadino Alonso del Castillo, Granada, 1991.

${ }_{23}$ Ould Mohamed Baba, al-Zajjali, n. ${ }^{\circ} 1986$.

24 Corriente y Bouzineb, Alonso del Castillo, n. ${ }^{\circ} 835$.

Al-Qanțara (AQ) XXVII 1, enero-junio 2006, pp. 105-135 ISSN 0211-3589 
siones, sale a relucir la buena reputación de la que gozaba la práctica de la pobreza voluntaria: «Salvarse de él [del mundo] es dejar cuanto hay en él» ${ }^{25}$. Este último aspecto viene confirmado por la información registrada en obras biográficas, donde la privación voluntaria se presenta como una cualidad virtuosa, sin que de ella se deriven repercusiones de índole social para quienes la practicaban ${ }^{26}$. Pero una de las características específicas de la vida contemplativa era el aislamiento voluntario de los ascetas. Por tanto, el hecho de que éstos viviesen al margen de las normas sociales comúnmente admitidas era susceptible de despertar un cierto recelo entre sus correligionarios. En esta percepción peyorativa puede haber influido la inactividad laboral de muchos de estos individuos, así como el hecho de vincularlos a los círculos místicos sufíes del período nazarí. Es bien sabido que a estos últimos se les acusaba de llevar una vida licenciosa, caracterizada por prácticas frívolas, poco ortodoxas y actos considerados de dudosa moralidad. Este colectivo era especialmente repudiado por las autoridades, quienes, por otro lado, temían la excesiva concentración de poder en manos de estos individuos, debido a la gran atracción que ejercían sobre las masas populares. Este último aspecto viene ilustrado por el hecho de que los místicos sufíes de época nazarí fuesen objeto de legados píos por parte de la población andalusí ${ }^{27}$.

En lo que respecta a la pobreza involuntaria, en general, cabe destacar la preponderancia de las connotaciones peyorativas inherentes al estado de pobreza frente a los escasos valores positivos que, en contrapartida, de él se derivaban. A los pobres involuntarios van dedicadas las siguientes páginas.

25 García Gómez, "Ibn Hišām", n. ${ }^{\circ} 95$.

${ }^{26}$ Sobre la integración y la marginación de los pobres voluntarios en al-Andalus, cfr. Carballeira, "Pobres y caridad en al-Andalus", 62-66 y 86-87. Para una información detallada sobre las prácticas ascéticas en los primeros tiempos del Islam andalusí, cfr. Marín, M., "The early development of zuhd in al-Andalus", Shï'a Islam, Sects and Sufism, F. de Jong (ed.) , Utrecht, 1992, 83-94; idem, "Retiro y ayuno: algunas prácticas religiosas de las mujeres andalusíes", Al-Qanțara, 21 (2000), 417-480; idem, "Zuhhäd de al-Andalus (300/912-420/1029)", Al-Qantara, 12 (1991), 439-469.

27 A este respecto véase Carballeira, "Pauvreté et fondations pieuses", 394-395; García Sanjuán, A., Hasta que Dios herede la tierra. Los bienes habices en Al-Andalus (siglos $X-X V$ ), Huelva, 2002, 202-211.

Al-Qanțara (AQ) XXVII 1, enero-junio 2006, pp. 105-135 ISSN 0211-3589 


\subsubsection{Aspectos negativos}

La pobreza resultaba especialmente denostada. En varios refranes es posible hallar una conexión directa entre pobreza y muerte, en la que ambos conceptos aparecen claramente identificados. Así se pone de manifiesto en un proverbio rimado de Ibn Luyūn:

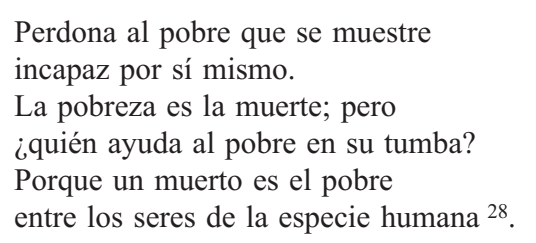

En determinados casos, la pobreza es objeto de una representación más concreta y específica: «La pobreza es la muerte roja» ${ }^{29}$. Esta expresión suele utilizarse en árabe para designar la muerte violenta. En otras ocasiones, si bien se recurre a otro tipo de imagen, permanece vigente esta misma asociación de ideas: «De no haberse arruinado las casas, no estarían llenas de tumbas» ${ }^{30}$.

En consonancia con el concepto de muerte, algunos refranes reflejan un clima pesimista, no sólo desechando cualquier posibilidad de recuperación económica por parte de un individuo después de haberse arruinado, sino también privándolo de toda consideración social. Al menos, así parece inferirse de la siguiente expresión: «El que ha empobrecido está acabado» ${ }^{31}$. Desde este punto de vista, tanto el aspecto social como el económico se hallan estrechamente ligados.

Asimismo, la pobreza era equiparada con otros conceptos cargados también de una cierta negatividad. Así consta en otro proverbio rimado de Ibn Luyūn, en el cual el mundo se manifiesta como un mal sueño, enumerándose las desgracias que asolan nuestra existencia terrenal. En este contexto, no deja de tener una cierta relevancia el paralelismo que se establece entre el concepto de pobreza y algunas nociones tan dispares como dolor, vejez y desunión:

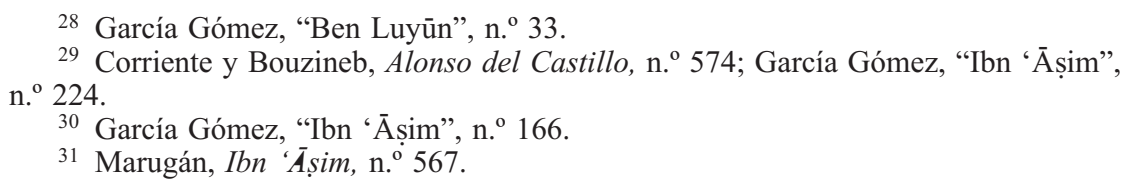

Al-Qanțara (AQ) XXVII 1, enero-junio 2006, pp. 105-135 ISSN 0211-3589 


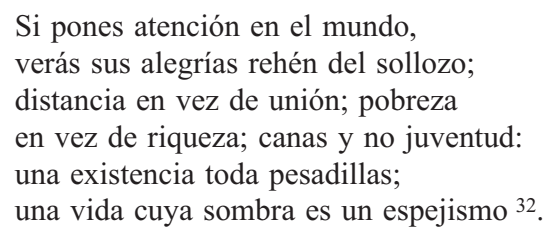

Todos los aspectos mencionados justifican que la miseria constituyese siempre un motivo de aflicción y pesadumbre para los afectados por ella: «[...] La pobreza entre amigos es cuita y tristeza» ${ }^{33}$. Algunas expresiones ponderan que ser pobre es el peor de los males, llegando a concebir la indigencia como una maldición divina: «Desgraciado aquél al que Dios no da nada» ${ }^{34}$. A estos sentimientos que inspiraba el estado de necesidad es preciso añadir la situación de humillación y postración que aquél entraña: «La pobreza no admite grandeza de ánimo» ${ }^{35}$. Del mismo modo, algunas virtudes y cualidades humanas, como la gentileza y la cortesía, eran susceptibles de sufrir menoscabo a causa del estado de privación que aquejaba a quienes lo padecían: «La escasez impide la caballerosidad» ${ }^{36}$. En esta misma línea, otra consecuencia de la vida mísera era el perjuicio que afectaba al entendimiento y que engendraba algunos defectos, como la ignorancia y la descortesía: «La miseria hace perder ciencia y educación» ${ }^{37}$. En ocasiones, las repercusiones derivadas de la escasez de recursos llegaban al extremo de poner en entredicho la probidad y la honradez de los afectados: «La miseria no deja hombría de bien, ni hay compañera que la acepte al no ver acoplo» ${ }^{38}$.

Pero, al margen del detrimento de los aspectos morales, algunos refranes se hacen eco de las secuelas físicas que la necesidad podía provocar: «La pobreza vuelve tartaja la lengua suelta y se lleva el lustre del rostro bonito» ${ }^{39}$. Asimismo, las malas condiciones de vida y la prolongación de un estado de necesidad acuciante podían acarrear se-

\footnotetext{
32 García Gómez, "Ben Luyūn", n. ${ }^{\circ} 44$.

33 Corriente y Bouzineb, Alonso del Castillo, n. ${ }^{\circ} 860$.

34 Ould Mohamed Baba, al-Zajjali, n. ${ }^{\circ} 1866$.

35 Marugán, Ibn 'Āșim, n. ${ }^{\circ} 154$.

36 Ould Mohamed Baba, al-Zajjali, n. ${ }^{\circ} 1332$.

7 Corriente y Bouzineb, Alonso del Castillo, n. ${ }^{\circ} 859$.

38 Ibídem, n. ${ }^{\circ} 102$.

39 García Gómez, "Ibn ‘Āṣim”, n. ${ }^{\circ} 223$.
} 
rios perjuicios para la salud: «De escasez sobre escasez resulta enfermedad» ${ }^{40}$.

Por otro lado, la literatura paremiológica también contiene referencias a la marginación que la población andalusí infligía a los pobres, poniéndose de manifiesto la vulnerabilidad de estos individuos ${ }^{41}$. Algunos refranes dejan traslucir las actitudes de desprecio y aversión que la gente necesitada suscitaba en el seno de la sociedad: «[...] El menesteroso es forastero en su pueblo» ${ }^{42}$, «La gente de Alhendín sale al pobre con escudo y cuchillo» ${ }^{43}$, «Deja al de escaso bien, que otros hay entre la gente» ${ }^{44}$, «Hemos padecido hambre, desnudez y desprecio de la gente» ${ }^{45}$. Incluso algunas expresiones no están exentas de un cierto tono supersticioso: «Si el pobre te llama a socorrerle, consulta, pues su estrella es de mal paso» ${ }^{46}$. En esta postura tiene mucho que ver el escaso interés que proporcionaba el contacto con el humilde, pues de él no se podían recabar los mismos beneficios que ofrecía el trato con el poderoso, tal y como veremos posteriormente. Para intentar completar el panorama que aquí se ofrece, es preciso traer a colación una referencia nada desdeñable relativa a la degradación de la condición humana en el período más alejado de la perfección, la cual en el pensamiento islámico tradicional se atribuye a los primeros tiempos del Islam. Entre los defectos que se mencionan, ocupa un lugar destacado la pobreza: «La gente en los últimos tiempos serán hábiles, inmorales, faltos de zapatos $\mathrm{y}$ escasos de sustento» ${ }^{47}$.

\subsubsection{Aspectos positivos}

Pero no todos eran prejuicios contra los pobres y su estado, como se pone de manifiesto en algunos refranes que denotan una actitud integradora hacia éstos por parte del prójimo ${ }^{48}$. Desde este punto de

40 Corriente y Bouzineb, Alonso del Castillo, n. ${ }^{\circ} 1365$.

41 También las obras históricas y biográficas contienen datos relativos al rechazo que los pobres suscitaban en al-Andalus; cfr. Carballeira, "Pobres y caridad en al-Andalus", 82-83.

42 García Gómez, “Al-'Iqd al-Farīd”, n. ${ }^{\circ} 110$.

43 Corriente y Bouzineb, Alonso del Castillo, n. ${ }^{\circ} 1201$.

${ }^{44}$ Marugán, Ibn 'Āṣim, n. ${ }^{\circ} 343$.

45 Ould Mohamed Baba, al-Zajjali, n. ${ }^{\circ} 780$.

${ }^{4}$ Corriente y Bouzineb, Alonso del Castillo, n. ${ }^{\circ} 1309$.

${ }^{47}$ Ibídem, n. ${ }^{\circ} 1221$.

48 Para una información complementaria sobre la integración de los pobres en el

Al-Qanțara (AQ) XXVII 1, enero-junio 2006, pp. 105-135 ISSN 0211-3589 
vista, el pobre era susceptible de aparecer como fuente de inspiración de sentimientos positivos. Así se infiere del concepto de justicia que se reclamaba para los pobres y que emana de algunas expresiones: «El dueño de lo escaso tiene más derecho a ello» ${ }^{49}$.

Asimismo, a la pobreza, al margen de sus innumerables inconvenientes, se le atribuían también algunas ventajas. De este modo, el despojo de todo atributo material podía traducirse en la ausencia de preocupaciones por la falta de responsabilidades: «El que se empobrece descansa» ${ }^{50}$, «El que no tiene casa no tiene vecino» ${ }^{51}$. Pero este principio perdía consistencia, ya que, como es natural, los pobres no quedaban al margen de las vicisitudes de la vida, pues tenían sus propias inquietudes, como se desprende del siguiente refrán, en el que el término «moscas» (dubbān) es una metonimia de la vida mísera: «Moscas con paz. Dijo él: La impiden» ${ }^{52}$.

No obstante, las consecuencias derivadas de la pobreza no afectaban por igual a todo el mundo, al menos, desde el punto de vista social, puesto que se advierten diferencias en función de la categoría social de cada individuo: «El hombre noble, noble es, aunque le caiga encima la miseria» ${ }^{53}$. Mientras que la mejora en el estado económico de un individuo podía condicionar su ascenso social, en el caso de la ruina de un personaje de alto rango, su posición social permanecía inalterable pese a las contingencias económicas a las que estaba sujeto, por lo que su consideración en el seno de la sociedad estaba por encima de cualquier factor de índole económica. Este aspecto permite entrever que el prestigio social no siempre se hallaba vinculado a la situación económica propiamente dicha. Incluso la enorme importancia que se concedía a los conceptos de honor y honra llegaba al extremo de sacrificar la riqueza material a riesgo de quedar sumido en la más absoluta pobreza. En este sentido, no es frecuente que se ensalcen las virtudes de la pobreza y se vituperen los defectos de la riqueza: «Compadezca Dios al hombre que protege su honor con su fortu-

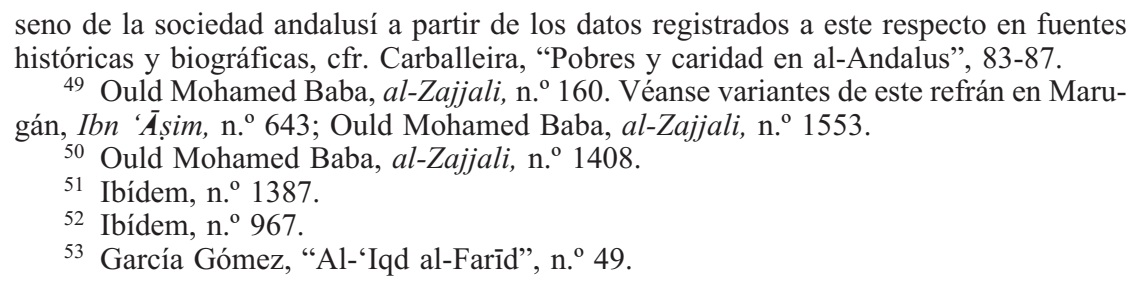


na» ${ }^{54}$. En este sentido se manifiesta también un proverbio rimado de Ibn Luyūn y lo hace en los siguientes términos:

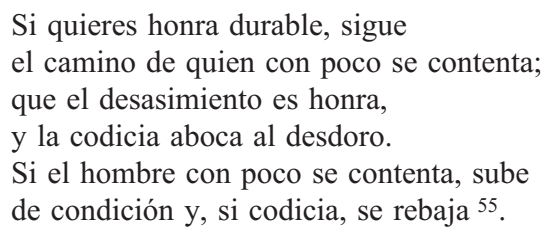

\subsection{Causas de la pobreza}

La literatura paremiológica andalusí nos instruye sobre algunos factores susceptibles de generar pobreza, ofreciendo un repertorio más amplio que el proporcionado por otro tipo de fuentes ${ }^{56}$. Los refranes revelan que las causas de pobreza en al-Andalus podían ser de muy diversa índole. En unos casos, se trataba de fenómenos externos, totalmente ajenos a la voluntad del individuo, impuestos por la sociedad en general o por su entorno familiar en particular, mientras que, en otras ocasiones, los hábitos de vida adoptados por los propios sujetos eran los que condicionaban sus avatares económicos.

Las frecuentes y continuas hambrunas que asolaron al-Andalus a lo largo de su historia permanecieron registradas en la memoria colectiva. Éstas podían ser originadas por fenómenos de distinta naturaleza, especialmente catástrofes naturales ${ }^{57}$. En general, la malnutrición afectaba a un gran número de personas y era causa de abundantes males. Dado que el hambre constituía un factor importante de pobreza y mortalidad, no es de extrañar la importancia que se le concedía al ámbito alimenticio. En este sentido, las expresiones proverbiales contienen abundantes reminiscencias a épocas de carestía y estrechez: «Más largo que el año del hambre» ${ }^{58}$, «Mundo sin comida, otro sería mejor» ${ }^{59}$. Este panorama explica la existencia de una constante preocupación por el avitua-

${ }^{54}$ Corriente y Bouzineb, Alonso del Castillo, n. ${ }^{\circ} 989$.

55 García Gómez, "Ben Luyūn”, n. ${ }^{\circ} 57$.

56 Respecto a las causas de pobreza contenidas en fuentes históricas y biográficas andalusíes, cfr. Carballeira, "Pobres y caridad en al-Andalus", 56-66.

57 Para más información sobre los diversos cataclismos que motivaron las crisis que azotaron al-Andalus entre los siglos IV/X-VI/XII, cfr. Ibídem, 56-59.

58 Marugán, Ibn 'Āssim, n. ${ }^{\circ} 23$.

59 Corriente y Bouzineb, Alonso del Castillo, n. . 262; Marugán, Ibn 'Āsim, n. ${ }^{\circ} 405$; Ould Mohamed Baba, al-Zajjali, n. ${ }^{\circ} 933$.

Al-Qanțara (AQ) XXVII 1, enero-junio 2006, pp. 105-135 ISSN 0211-3589 
llamiento: «La preocupación por la cena y el almuerzo no se acaba nunca» ${ }^{60}$. Este afán aparece también reflejado en jaculatorias de tipo religioso: «Dios no nos castigue con hambre» ${ }^{61}$. La imperiosa necesidad de dejar bien cubiertas las necesidades materiales más elementales justifica el carácter prioritario que se concede a la alimentación, anteponiéndola incluso a las obligaciones religiosas que el hombre tiene contraídas: «El horno se construyó antes que la mezquita» ${ }^{62}$.

Los refranes andalusíes nos ilustran también sobre otras posibles causas de pobreza. Algunas se hallan estrechamente vinculadas a los rasgos de la personalidad de cada individuo. Así, por ejemplo, el exceso de generosidad podía entrañar perjuicios para quienes despilfarraban sus medios de subsistencia: "Si promete mucho, empobrece» ${ }^{63}$. Este último aspecto aparece registrado en la literatura biográfi$\mathrm{ca}$, donde se pone de manifiesto que la magnanimidad desmesurada de un individuo podía deteriorar su poder adquisitivo ${ }^{64}$. Otro tanto de lo mismo sucede con los efectos negativos derivados de ciertos vicios o defectos morales, como es el caso de la gula y la fornicación: «El que consiente a su vientre y a su pene ve sus bienes en manos ajenas» ${ }^{65}$, «Recoger migajas, lamer vasijas y dejar la fornicación engendran riqueza» ${ }^{66}$. De esta última expresión se desprende que, frente a las perniciosas consecuencias que se derivaban del despilfarro, otra posible forma de evitar caer en la miseria era la recomendable práctica del ahorro y la morigeración.

Desde el punto de vista social, un elemento que podía influir desfavorablemente en la economía familiar era el esforzarse en mantener un nivel de vida acorde con una determinada categoría social: «La conveniencia empobrece» ${ }^{67}$. Asimismo, el hecho de contraer matrimonio era susceptible de erosionar los recursos disponibles, debido a los gastos que originaba el mantenimiento de cónyuge/s y prole: «El que es desposado se vuelve necesitado» ${ }^{68}$, «Pocos hijos es segunda

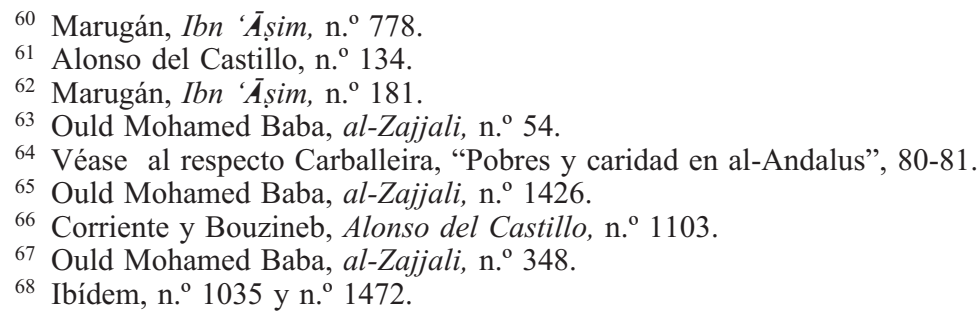


riqueza» ${ }^{69}$. Pero también los hijos podían ser víctimas de la precariedad económica de sus progenitores: «Los hijos de aquél al que las preocupaciones han apabullado pasan hambre» ${ }^{70}$.

Asimismo, como veremos posteriormente, la animadversión al trabajo podía convertirse en foco de miseria: «La holgazanería es la puerta de la pobreza y el afán es madre del bienestar» ${ }^{71}$. Pero el desempeño de una profesión no siempre garantizaba la prosperidad económica. Algunas expresiones nos informan de las vicisitudes económicas que podían afectar a quienes se dedicaban a ciertos menesteres: «Más pobre que el maestro de Berja, que tenía un bonete de esparto y su percha era de caña» ${ }^{72}$, «Más pobre que el cadí de Alcalá, que juzgaba de día y mendigaba de noche» ${ }^{73}$, «Más pobre que el alcaide de Saviote que remendaba su alcabtea con cáscaras de badea» ${ }^{74}$, «Más pobre que el alcalde de Alcalá, que robó una agujeta del tambor para hacer el lazo de su zapato» ${ }^{75}$. Resulta curioso que estos refranes recogidos en el siglo VII/XIII por al-Zaŷŷālī no aparezcan registrados en refraneros andalusíes precedentes ni posteriores. Es posible que estas expresiones hiciesen referencia a individuos particulares que en un lugar y en un momento determinados representaron el prototipo de pobre, quedando relegado el uso de las mismas a unas coordenadas geográfico-temporales limitadas. Asimismo, no debe descartarse la posibilidad de que la supuesta pobreza de estos personajes fuese exagerada en estos refranes, ya que éstos contienen una evidente carga satírica, al referirse a altos cargos públicos. En cualquier caso, resultaría muy aventurado extraer conclusiones generales a partir de unos ejemplos tan puntuales, exceptuando el caso del maestro, ya que en otro tipo de fuentes existe constancia de las necesidades padecidas por quienes se dedicaban a la enseñanza. En relación con este último aspecto, cabe señalar que el analfabetismo se contemplaba como una posible causa de pobreza. Así parece inferirse de la importancia que el refranero andalusí concede a la formación intelectual: «Quien sabe leer, no se verá en la miseria» ${ }^{76}$.

69 García Gómez, "Al-'Iqd al-Farīd”, n. ${ }^{\circ} 40$.

${ }^{70}$ Ould Mohamed Baba, al-Zajjali, n. ${ }^{\circ} 1390$.

71 Corriente y Bouzineb, Alonso del Castillo, n. ${ }^{\circ} 83$.

72 Ould Mohamed Baba, al-Zajjali, n. ${ }^{\circ} 511$.

3 Ibídem, n. ${ }^{\circ} 485$.

${ }^{74}$ Ibídem, n. ${ }^{\circ} 483$

Ibídem, n. ${ }^{\circ} 484$.

${ }^{76}$ Corriente y Bouzineb, Alonso del Castillo, n. ${ }^{\circ}$ 196; Marugán, Ibn 'Āssim, n. 579.

Al-Qanțara (AQ) XXVII 1, enero-junio 2006, pp. 105-135 ISSN 0211-3589 
Esta circunstancia tiene su contrapunto en la estrechez económica por la que atravesaban individuos instruidos en al-Andalus, no sólo maestros, sino también poetas y hombres de letras ${ }^{77}$.

Por otro lado, el ejercicio de cargos más o menos relevantes de la administración andalusí, tales como alcaides y cadíes, no implicaba la inmunidad de estos individuos frente a la pobreza. A la posible mala gestión del estipendio que recibían por el desempeño de sus funciones es preciso añadir que en ocasiones la labor profesional era asumida de forma desinteresada. De hecho, esta conducta se halla ampliamente documentada en la literatura biográfica andalusí, especialmente en lo que respecta a personajes del ámbito jurídico, como cadíes y alfaquíes, algunos de los cuales adoptaban un estilo de vida modesto y humilde, caracterizado por la privación voluntaria ${ }^{78}$. Sin embargo, las obras biográficas guardan silencio en torno a los avatares económicos de los alcaides de castillos o fortalezas. Si bien la referencia recogida en este sentido por al-Zaŷŷālī podría estar en conexión con la pobreza voluntaria del alcaide en cuestión vinculada a un ideal ascético ${ }^{79}$, tampoco se debe soslayar la posibilidad de que se trate de un caso de privación involuntaria, dado que este tipo de edificaciones sólo contaba con los recursos procedentes de iniciativas particulares, como es el caso del establecimiento de legados píos a fin de sufragar sus necesidades ${ }^{80}$. De esta circunstancia se infiere la penuria económica que afectaba a las fortalezas que no resultaban beneficiadas por este tipo de donativos.

Otra profesión que llevaba implícitas repercusiones de índole económica para quienes la desempeñaban era la de músico. Al aspecto

77 Carballeira, "Pobres y caridad en al-Andalus", 61-62.

78 Respecto a la práctica de la privación voluntaria en el ámbito jurídico andalusí, cfr. Carballeira, "Pobres y caridad en al-Andalus", 64-65.

79 Existe constancia de la práctica de retiro espiritual de ulemas en rábitas ubicadas en la frontera con los reinos cristianos del Norte peninsular a partir del siglo V/XI. Cfr. a este respecto Carballeira, Legados píos, 144, nota 196; Marín, M., "Los ulemas de Toledo en los siglos IX/X y V/XI", en Actas del Congreso Internacional "Entre el Califato y la Taifa: mil años del Cristo de la Luz" (Toledo, 1999), Toledo, 2000, 80-81.

${ }^{80}$ Sobre los legados píos destinados a fortalezas rurales en al-Andalus, cfr. Carballeira, Legados píos, 140-148; García Sanjuán, A., "Frontera, ŷihād y legados piadosos en Al-Andalus (siglos X-XV)", en Toro Ceballos, F. y Rodríguez Molina, J. (coords.), III Estudios de Frontera. Convivencia, defensa y comunicación en la Frontera, Jaén, 2000, 324-325; idem, Hasta que Dios herede la tierra, 195-196; Marín, M., "Documentos jurídicos y fortificaciones", en Actas del I Congreso Internacional de Fortificaciones en al-Andalus, Cádiz, 1998, 81-82.

Al-Qanțara (AQ) XXVII 1, enero-junio 2006, pp. 105-135 ISSN 0211-3589 
económico es preciso añadir el estigma social que iba asociado a este oficio. Los músicos, especialmente los pertenecientes a la 'āmma, eran denostados por dedicarse a actividades livianas y censurables desde el punto de vista ético, poniéndose en entredicho su integridad moral ${ }^{81}$. Ya hemos visto que en otros refranes los vicios morales se contemplaban como causa de miseria. La vida mísera de los músicos queda patente en algunas expresiones: "Tañer y comer porquería» ${ }^{82}$, «Nosotros estudiamos y no prosperamos, ¿cómo sería si cantásemos?» ${ }^{83}$. Esta última expresión debe ponerse en relación con los ya mencionados apuros económicos por los que atravesaban los hombres de letras, los poetas y quienes consagraban su vida a la enseñanza.

En relación con todos estos aspectos, no debe soslayarse el hecho de que también el llevar una vida errante redundaba en el padecimiento de sacrificios y sufrimientos: «Quien cruza río y camino no desconoce miseria» ${ }^{84}$. Este refrán corrobora la información registrada en obras históricas y biográficas, donde se pone de manifiesto que las penurias que soportaban los caminantes o transeúntes (ahl al-sabïl) hacía que éstos fuesen objeto de atenciones por parte de la población andalusí, siendo receptores de limosnas y donativos ${ }^{85}$.

Finalmente, en este contexto no es superfluo traer a colación la trascendencia que el ejercicio de un oficio no sólo tenía en el poder adquisitivo de un individuo, sino también en su consideración social. Determinadas profesiones se hallaban desacreditadas, independientemente de la holgura económica que proporcionaban ${ }^{86}$. Así, por ejemplo, el refranero andalusí, además de ilustrarnos sobre la próspera situación económica del campesinado: «Pobre y campesino no suena» ${ }^{87}$, también

${ }^{81}$ Respecto a la mala fama derivada de este tipo de ocupaciones, cfr. Brunschvig, R., "Métiers vils en Islam", Studia Islamica, 16 (1962), 46; Carballeira, A.M., "La introduccción de Ibn 'Abd al-Malik al-Marrākušī a su al-Dayl wa-l-Takmila”, en Ávila, M. L. y Fierro, M. (eds.), EOBA X (Biografias almohades. II), Madrid-Granada, 2000, 200-201; Tahiri, A., Las clases populares en al-Andalus, Málaga, 2003, 100.

82 Ould Mohamed Baba, al-Zajjali, n. ${ }^{\circ} 1032$.

${ }^{83}$ Ibídem, n. $^{\circ} 1551$.

${ }^{84}$ Corriente y Bouzineb, Alonso del Castillo, n. ${ }^{0} 127$.

85 Al respecto véase Carballeira, "Pauvreté et fondations pieuses", 398; idem, "Pobres y caridad en al-Andalus", 68 .

${ }_{86}$ En lo que se refiere a la disparidad existente entre los diferentes oficios, cfr. Brunschvig, "Métiers vils en Islam", 41-60; Rubiera, M. J., "Oficios nobles, oficios viles”, en Viguera, M. J. (ed.), La mujer en al-Andalus: reflejos históricos de su actividady categorias sociales, Madrid-Sevilla, 1989, 71-76.

87 Ould Mohamed Baba, al-Zajjali, n. ${ }^{\circ} 1775$.

Al-Qanțara (AQ) XXVII 1, enero-junio 2006, pp. 105-135 ISSN 0211-3589 
nos revela que su economía saneada no influía positivamente en su valoración social: «Al campesino y al ratón, no les indiques tu casa» ${ }^{88}$, "Aunque el campesino fuera de seda, sus labios serían de estera» ${ }^{89}$, «Como hortelano, róbale pero no le pidas» ${ }^{90}$.

\subsection{Formas de contrarrestar la pobreza}

La pobreza provocaba distintas reacciones entre los afectados y el prójimo con vistas a intentar paliar los efectos perniciosos que de ella se derivaban y mejorar así el estado económico de los más desvalidos. Los refranes nos permiten conocer estos procedimientos. De algunos de ellos existe constancia en otro tipo de fuentes, que avalan este tipo de información ${ }^{91}$. En otros casos, las fórmulas proverbiales aportan nuevos datos a este respecto, contribuyendo a completar la visión parcial ofrecida por otro tipo de documentación.

\subsubsection{Medidas adoptadas por los pobres}

En general, la forma de actuar de los pobres dependía de su estado de necesidad, así como de su capacidad de iniciativa: «[...] Quien no tiene oficio ni bienes se las ingenia [...]» ${ }^{92}$. Esta información de índole general viene contrastada y matizada por datos más concretos contenidos en el refranero andalusí.

En ocasiones, existe constancia de disposiciones tomadas con motivo de situaciones caracterizadas por un cierto dramatismo. Precisamente, en relación con las ya conocidas crisis socio-económicas que afectaron al territorio andalusí, la literatura paremiológica nos informa de que una forma de reacción de la población era la emigración, cuando la gravedad de la situación llegaba a límites insostenibles: «Cuando llega la plomiza a la tierra de una gente, sus habitantes han de marcharse» ${ }^{93}$. Este modo de proceder está ampliamente documen-

${ }^{88}$ Corriente y Bouzineb, Alonso del Castillo, n. ${ }^{\circ} 53$.

89 Ibídem, n. ${ }^{\text {o }} 120$.

${ }^{90}$ Ibídem, n. $^{\circ} 818$

91 Respecto a la información registrada sobre el particular en crónicas y obras biográficas andalusíes, cfr. Carballeira, "Pobres y caridad en al-Andalus", 66-82.

${ }_{92}$ Corriente y Bouzineb, Alonso del Castillo, n. ${ }^{\circ} 1474$.

93 Ibídem, n. ${ }^{\text {o }} 180$.

Al-Qanțara (AQ) XXVII 1, enero-junio 2006, pp. 105-135 ISSN 0211-3589 
tado en al-Andalus, ya que la cronística también se hace eco de esta realidad social, registrando la huida masiva de andalusíes a otras zonas de la Península Ibérica y del Norte de África que permanecían al margen de las crisis ${ }^{94}$. En cualquier caso, no se debe perder de vista que los refranes también contienen referencias a la determinación contraria, es decir, a la permanencia en el país de origen: «Quien ha soportado el hambre en su país, conseguirá su prosperidad» ${ }^{95}$.

En otros casos, la gravedad de la situación se deduce de la adopción de ciertas medidas drásticas por parte de los afectados. En general, se trata de procedimientos poco honestos, como el hurto y la prostitución, a los que recurre el pobre para intentar aliviar la estrechez en la que se halla sumido: «Cuando el hombre tiene holgura, se deprava, $\mathrm{y}$, cuando se empobrece, roba» ${ }^{96}$, «La disculpa de la hija de la panadera, que se prostituía, porque su padre quemaba las cazuelas» ${ }^{97}$. Quizás la puesta en práctica de métodos tan poco ortodoxos explique el que se atribuya al estado de pobreza el menoscabo de la honradez de los afectados por ella, aspecto al que anteriormente me he referido.

Asimismo, entre los diversos procedimientos a los que se recurría para afrontar la pobreza, cabe destacar la controvertida práctica de la mendicidad. Si bien son escasísimos los datos contenidos a este respecto en obras históricas y biográficas andalusíes ${ }^{98}$, las referencias presentes en el refranero andalusí revisten una especial relevancia, pues permiten presuponer con una mayor certidumbre la existencia de la mendicidad en al-Andalus, además de proporcionar información más precisa y exacta sobre las implicaciones que se derivaban de este concepto. De este modo, se puede llegar a dilucidar cómo eran percibidos los mendigos por el resto de la sociedad.

94 Carballeira, "Pobres y caridad en al-Andalus", 56 y 66-67.

95 Marugán, Ibn 'Āsim, n. ${ }^{\circ} 560$.

96 Corriente y Bouzineb, Alonso del Castillo, n. ${ }^{\circ}$ 737. En al-Andalus está documentado un considerable aumento de actos delictivos en épocas de carestía, al recurrirse al hurto y al crimen con el fin de paliar la penuria económica de la gente; cfr. Carballeira, "Pobres y caridad en al-Andalus", 67.

97 Corriente y Bouzineb, Alonso del Castillo, n. ${ }^{\circ} 1100$. Respecto a la práctica de la prostitución en al-Andalus, cfr. Marín, M., Mujeres en al-Andalus, Madrid, 2000, 302-305. En concreto, sobre la prostitución en la literatura paremiológica, cfr. Lachiri, "Andalusi Proverbs on Women", 45-46.

98 Sobre la parquedad de las fuentes en torno a esta cuestión, cfr. Carballeira, "Pobres y caridad en al-Andalus", 70.

Al-Qanțara (AQ) XXVII 1, enero-junio 2006, pp. 105-135 ISSN 0211-3589 
Algunas expresiones paremiológicas ponen de manifiesto el carácter negativo intrínseco a la mendicidad: «Tener que pedir a otros es el mayor baldón» ${ }^{99}$, «Dios me libre de enfermedad larga, mirada sin desvío y escasez con mendicidad» ${ }^{100}$, «Como leproso que mendiga con su hermana» ${ }^{101}$. En este último caso, la connotación peyorativa inherente a la mendicidad aparece intensificada por la referencia a una enfermedad como la lepra, susceptible de suscitar rechazo social ${ }^{102}$. Asimismo, no deja de ser relevante la identificación que se hace del concepto de mendicidad con el de ociosidad en el siguiente refrán: «Descansa el culo de quien mendiga» ${ }^{103}$, pues no se debe olvidar lo mal vista que estaba la desidia laboral, contra la cual se recomendaba encarecidamente el recurso al trabajo. Así pues, los diversos aspectos negativos que se derivan de la noción de mendicidad explican el afán existente por mejorar el estado de los mendigos: «Si la plegaria se cumpliera, los mendigos enriquecieran» ${ }^{104}$. Finalmente, para completar este panorama, no se deben pasar por alto los riesgos que revestía la práctica de la caridad con el mendigo y que podrían resumirse en la creación de un cierto hábito por parte del pedigüeño. Así se pone de manifiesto en un par de refranes: «Compadécete del mendigo y se te convertirá en socio» ${ }^{105}$, «Le enseñamos la mendicidad y le ganó a las rodillas»» ${ }^{106}$.

A pesar de esta imagen peyorativa de la mendicidad, en determinados casos se constata la existencia de una postura libre de prejuicios hacia ella. Así, se recomienda su puesta en práctica en circunstancias extremas y se da una serie de consejos a los interesados para asegurar su efectividad. Estas advertencias hacen hincapié en el he-

99 García Gómez, "Ibn 'Āșim”, n. ${ }^{\circ} 224$.

100 Corriente y Bouzineb, Alonso del Castillo, n. ${ }^{\circ} 926$.

101 Ibídem, n. ${ }^{\circ} 1620$.

102 Las fuentes jurídicas informan de las escasas repercusiones sociales derivadas de la lepra en al-Andalus para los afectados por ella en los siglos IV/X-VI/XII; cfr. Carballeira, Legados píos, 186-187; Mazzoli-Guintard, C., "Notes sur une minorité urbaine d'al-Andalus: les lépreux", Homenaje al profesor Carlos Posac Mon, I, Ceuta, 1998, 22-23. Sin embargo, los datos proporcionados por la literatura paremiológica andalusí apuntan a una mayor marginación social de este colectivo, si bien en una época más tardía; cfr. Corriente y Bouzineb, Alonso del Castillo, n. ${ }^{\circ} 65$ y n. ${ }^{\circ} 870$; Marugán, Ibn 'Āsim, n. ${ }^{\circ}$ 6; Ould Mohamed Baba, al-Zajjali, n. ${ }^{\circ} 1676$.

${ }_{103}$ Marugán, Ibn 'Āsim, n. ${ }^{\circ} 736$.

${ }^{104}$ Corriente y Bouzineb, Alonso del Castillo, n. ${ }^{\circ} 79$.

105 Ibídem, n. ${ }^{\circ} 200$.

${ }^{106}$ Ibídem, n. ${ }^{\circ} 1070$.

Al-Qanțara (AQ) XXVII 1, enero-junio 2006, pp. 105-135 ISSN 0211-3589 
cho de desplegar una cierta habilidad, adoptando una serie de tácticas que redunden en beneficio de los afectados. En general, se trata de actuar haciendo gala de osadía y perseverancia para asegurarse los mejores resultados: «La mendicidad, con insistencia, y el corretaje, con desvergüenza» ${ }^{107}$. De forma particular, se exhorta a recurrir a la ayuda del poderoso, puesto que, en realidad, sólo él dispone de los recursos necesarios para proporcionar el auxilio pertinente y mejorar la calidad de vida del débil: «Si sufres la necesidad de mendigar, acude a las casas grandes» ${ }^{108}$. Por este motivo, resultaba fundamental saber elegir al interlocutor oportuno: «Vale más dejar pasar la necesidad que pedir ayuda a quien no debemos hacerlo» ${ }^{109}$.

Los refranes andalusíes también contienen una serie de consejos generales destinados a quienes han caído en la miseria, con el fin de hacerla lo más llevadera posible. De este modo, en las adversidades se recomienda afrontar los problemas con resignación: «La ropa de humillación ha de vestirse, y al mono se le baila cuando manda, y hay gozo en la pobreza como el de la riqueza» ${ }^{110}$, «El consuelo del pobre: no hay más riqueza que la salud» ${ }^{111}$. Asimismo, se exhorta a adoptar una actitud de moderación y templanza con respecto a los bienes materiales: «Amengua tus apetitos y te será llevadera la pobreza» ${ }^{112}$. Ya hemos visto previamente que la recomendación al ahorro también tenía como finalidad evitar caer en la miseria.

En otros casos, aunque no siempre se trata de buscar soluciones definitivas al estado de necesidad, esa posibilidad no pasa del todo desapercibida, para lo cual se preconiza de forma insistente como mejor terapia el recurso al propio trabajo: «No remediará tu pobreza más que lo que gane tu mano» ${ }^{113}$. Esta postura es la tónica general en el refranero andalusí, el cual contiene numerosas expresiones que incitan al trabajo, desaconsejando la ociosidad, ya sea para afrontar la pobreza, ya sea para prevenirla.

107 Ould Mohamed Baba, al-Zajjali, n. ${ }^{\circ} 321$.

108 Marugán, Ibn 'Āsim, n. ' 29; Ould Mohamed Baba, al-Zajjali, n. ${ }^{\circ} 49$. Este aspecto viene confirmado por la cronística; cfr. Carballeira, "Pobres y caridad en al-Andalus", 69 .

109 García Gómez, "Ibn ‘Āṣim”, n. 255.

110 Corriente y Bouzineb, Alonso del Castillo, n. ${ }^{\circ} 1354$.

111 Ould Mohamed Baba, al-Zajjali, n. ${ }^{\circ} 726$.

112 García Gómez, "Ibn 'Āsim”, n. ${ }^{\circ} 274$.

113 García Gómez, “Al-‘Iqd al-Farīd”, n. ${ }^{\circ} 108$.

Al-Qanțara (AQ) XXVII 1, enero-junio 2006, pp. 105-135 ISSN 0211-3589 
Pero, además de dar cuenta de las medidas adoptadas por los pobres para afrontar e intentar mitigar la penuria económica en la que se hallan, el refranero andalusí nos proporciona algunos ejemplos ilustrativos sobre la actitud que estos individuos tenían de su propio estado y condición. De este modo, es posible recabar información sobre algunos aspectos que caracterizan al pobre vergonzante en la vida cotidiana ${ }^{114}$. En muchos casos, se trataba de personas de una relevante categoría socio-económica que, venidas a menos, intentaban salvaguardar su posición social, encubriendo y disimulando su precariedad económica, a fin de evitar la exposición pública de su miseria: «Pobre con bordados, mendicante con balanza de orfebre» ${ }^{115}$, «Vivir siempre retirado ayuda a disimular la situación económica» ${ }^{116}$. En otros casos, el empeño en rehuir la humillación social inherente al estado de pobreza podía afectar no sólo al mantenimiento de la apariencia física, sino también al carácter de estos individuos, permitiendo perfilar mejor algunos rasgos de su personalidad: «Presuntuoso y necesitado» ${ }^{117}$, «Pobreza con arrogancia» ${ }^{118}$. Sin embargo, pese a los esfuerzos desplegados por los pobres vergonzantes en este sentido, éstos no siempre veían cumplidos sus objetivos: "Al que oculta el hambre, en la cara le aparece» ${ }^{119}$. Quizás por la escasa utilidad que se obtenía de simular prosperidad económica, se recomendaba aparentar pobreza en caso de debilidad: «Hazte el pobre hasta que estés fuerte» ${ }^{120}$.

\subsubsection{Medidas adoptadas por el prójimo}

Al margen de los procedimientos empleados por la gente necesitada para intentar mejorar su estado económico, el refranero andalusí también nos instruye sobre las iniciativas desplegadas por el prójimo en este sentido ${ }^{121}$. En muchos casos, los pobres dependían de la cari-

114 Asimismo, las fuentes históricas y biográficas nos proporcionan datos referentes a la existencia de pobres vergonzantes en al-Andalus; cfr. Carballeira, "Pobres y caridad en al-Andalus", 82.

115 Corriente y Bouzineb, Alonso del Castillo, n. ${ }^{\circ} 452$.

116 García Gómez, "Ibn 'Āșim”, n. ${ }^{\circ} 85$.

117 Ould Mohamed Baba, al-Zajjali, n. ${ }^{\text {o }} 1577$.

118 Ibídem, n. ${ }^{\circ} 180$.

119 Ibídem, n. ${ }^{\circ} 1406$.

120 Ibídem, n. ${ }^{\circ} 461$.

121 Es preciso completar este panorama con la información procedente de textos históricos y biográficos en relación con las iniciativas adoptadas a este respecto por la po- 
dad ajena. En general, algunas expresiones paremiológicas son elocuentes respecto a la generosidad dispensada por la población andalusí: «Reparte lo que tiene entre los aprendices» ${ }^{122}$, «De él se come $\mathrm{y}$ con él se duerme» ${ }^{123}$, «Nos hemos puesto ropa $\mathrm{y}$ hemos dado ropa» ${ }^{124}$.

No es frecuente que en el refranero andalusí se mencione expresamente la identidad del receptor de la caridad. No obstante, pese al claro predominio de referencias generales a este respecto, ciertas expresiones nos informan sobre algunos de los donatarios considerados más merecedores de limosna 125: «Los parientes son los más dignos de favor» ${ }^{126}$, «Si es una limosna, los ciegos son más merecedores de ella» ${ }^{127}$, «Ten piedad de mí, de Xudayyar y de los leprosos que están sobre el borriquillo» ${ }^{128}$, «El huérfano es más merecedor de ser declarado insolvente» ${ }^{129}$. Otro tipo de fuentes nos ilustran sobre otras cate-

blación andalusí; cfr. Carballeira, "Pobres y caridad en al-Andalus", 70-82. La caridad se podía manifestar mediante la distribución de limosnas o el establecimiento de legados píos (ạ̣bās jayriyya). Véase bibliografía relativa al azaque o zakāt (limosna preceptiva) y la șadaqa (limosna voluntaria) en Carballeira, "Pobres y caridad en al-Andalus", 55, nota 3. Respecto a los legados píos para pobres en al-Andalus, cfr. Carballeira, Legados píos, 169-183; idem, "Pauvreté et fondations pieuses", 391-416; García Sanjuán, Hasta que Dios herede la tierra, 180-183.

122 Marugán, Ibn 'Āṣim, n. ${ }^{\circ} 830$.

123 Ould Mohamed Baba, al-Zajjali, n. ${ }^{\circ} 159$.

124 Ibídem, n. ${ }^{\circ} 389$.

125 Según el Corán, los pobres (fuqarā') y los menesterosos (masākinn) eran merecedores del azaque, junto con los limosneros, aquéllos cuya voluntad hay que captar, la redención de cautivos, los insolventes, la causa de Dios y los viajeros; cfr. al respecto Carballeira, Legados píos, 169; idem, "Pobres y caridad en al-Andalus", 55.

126 Marugán, Ibn 'Ásim, n. ${ }^{\circ} 192$. En efecto, a la práctica de la caridad en el seno familiar se le otorgaba una gran estima. Las fuentes jurídicas nos informan sobre la existencia de un especial desvelo por los parientes necesitados en al-Andalus, al registrarse un

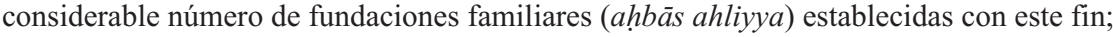
cfr. Carballeira, Legados píos, 223-224; García Sanjuán, Hasta que Dios herede la tierra, 153-154.

127 Ould Mohamed Baba, al-Zajjali, n. ${ }^{\circ}$ 156. En al-Andalus los ciegos eran objeto de legados píos; cfr. Carballeira, Legados píos, 225; García Sanjuán, Hasta que Dios herede la tierra, 185.

128 Marugán, Ibn 'Āssim, n. ${ }^{\circ} 257$. También los leprosos eran receptores de fundaciones pías; cfr. Carballeira, Legados píos, 183-189; García Sanjuán, Hasta que Dios herede la tierra, 184-187.

129 Ould Mohamed Baba, al-Zajjali, n. ${ }^{\circ}$ 161. Dentro de la categoría de pobres no se debe dejar de incluir a huérfanos y viudas. La literatura paremiológica se revela como la más explícita en informaciones relativas al estado de estos dos colectivos, saliendo a relucir su estrechez económica, así como las repercusiones sociales que de esta circunstancia se derivaban para el estado de sus componentes; cfr. Corriente y Bouzineb, Alonso del

Al-Qanțara (AQ) XXVII 1, enero-junio 2006, pp. 105-135 ISSN 0211-3589 
gorías de desamparados que eran objeto de limosnas y atenciones en al-Andalus ${ }^{130}$. No obstante, ya hemos visto que los pobres podían llegar a suscitar una cierta reticencia a ser objeto de caridad por parte del prójimo: «Si el pobre te llama a socorrerle, consulta, pues su estrella es de mal paso» ${ }^{131}$.

Pero los individuos más desfavorecidos no sólo eran potenciales receptores de limosnas, sino que, dentro de sus limitadas posibilidades, podían dar muestras de largueza y desprendimiento: «El pobre es generoso con lo que tiene» ${ }^{132}$, "'Ayša, que no tiene nada que lamer, a los vecinos se lo da en limosna» ${ }^{133}$. En cualquier caso, no pasan desapercibidas las dificultades que este hecho entrañaba para quienes estaban sumidos en la miseria más absoluta: «El pobre no presta» ${ }^{134}$, «Con pobreza no se puede dar limosna» ${ }^{135}$.

El principal cometido de la caridad era el de mitigar las carencias materiales: «La limosna aparta la calamidad del hombre sin que éste lo sepa» ${ }^{136}$. En la versión del refranero de Ibn 'Āṣim realizada por E. García Gómez son constantes las incitaciones a practicar la caridad y la generosidad con el prójimo: «Llena tus horas de buenas acciones» ${ }^{137}$, «El día peor es aquél en que no haces el bien» ${ }^{138}$. Esta conducta sirve

Castillo, n. ${ }^{\circ} 50$ n $^{\circ}{ }^{\circ} 909$, n. $^{\circ} 1028$, n. $^{\circ} 1074$ y n. ${ }^{\circ} 1202$; Marugán, Ibn 'Āsim, n. ${ }^{\circ} 391$; Ould Mohamed Baba, al-Zajjali, n. ${ }^{\circ} 196$, n. $^{\circ} 1067$ y n. ${ }^{\circ} 2063$. Una información de índole general sobre huérfanos y viudas puede obtenerse en Carballeira, "Pobres y caridad en al-Andalus", 67. En concreto, sobre el estado de las viudas en al-Andalus, cfr. Marín, Mujeres en al-Ándalus, 496-503.

130 Carballeira, "Pobres y caridad en al-Andalus", 68, nota 71; idem, "Pauvreté et fondations pieuses", 394-399. Concretamente, en este último trabajo he pasado revista a algunos colectivos que eran objeto de legados píos en función del estado de necesidad que les infligían sus respectivas ocupaciones. A este respecto, debo advertir que existe la posibilidad de que, en determinados casos, no se tratase de gente necesitada y que la constitución de legados píos en beneficio de determinados colectivos se contemplase como un procedimiento de remunerar el ejercicio de ciertos oficios, como es el caso de vigilantes nocturnos y lectores de partes de guerra.

131 Corriente y Bouzineb, Alonso del Castillo, n. ${ }^{\circ} 1309$.

132 Ibídem, n. ${ }^{\circ} 895$.

${ }^{133}$ Marugán, Ibn 'Āṣim, n. ${ }^{\circ}$ 675. La literatura biográfica andalusí atestigua la existencia de donativos dispensados por gente humilde que se desprendía de los escasos recursos que tenía para ayudar al prójimo necesitado; cfr. a este respecto Carballeira, "Pobres y caridad en al-Andalus", 80-81.

134 Ould Mohamed Baba, al-Zajjali, n. ${ }^{\circ} 374$.

135 García Gómez, "Al-'Iqd al-Farīd", n. ${ }^{\circ} 148$.

136 Corriente y Bouzineb, Alonso del Castillo, n. ${ }^{0} 764$.

137 García Gómez, "Ibn 'Āsim”, n. ${ }^{\text {o }} 237$.

138 García Gómez, “Ibn ‘Āṣim”, n. 295.

Al-Qanțara (AQ) XXVII 1, enero-junio 2006, pp. 105-135 ISSN 0211-3589 
de baremo para evaluar los méritos personales de cada individuo: «El hombre vale lo que valen sus buenas acciones» ${ }^{139}$, «El mejor de los hombres es el más útil a los demás» ${ }^{140}$. Estas incitaciones a la caridad personal revelan que la limosna se concebía como una responsabilidad individual ${ }^{141}$. En general, estas expresiones están impregnadas de un claro contenido religioso, que viene muy bien ilustrado por la siguiente expresión: «La vestidura del temor de Dios es para el hombre una ropa que lo cubre y la vestidura del pecado es para él una ropa que lo deja al desnudo» ${ }^{142}$. Se infiere, por tanto, la importancia del carácter preceptivo de la caridad, ya que su incumplimiento podía entrañar serias consecuencias: «La gala de la otra vida son las [buenas] acciones» ${ }^{143}$, «Ve al encuentro de Dios con mil limosnas y no vayas a su encuentro ni con un solo pecado» ${ }^{144}$. Pero, además de las consabidas virtudes, el refranero andalusí también nos ilustra sobre algunos inconvenientes inherentes a la solidaridad humana: «Demasiada generosidad produce cuernos» ${ }^{145}$. En este contexto, cabe traer a colación la adicción y dependencia que los actos caritativos fomentaban en el donatario y que, anteriormente, ya hemos visto aplicados al mendigo: "Comparte tus bienes con el pobre, se te volverá cofrade» ${ }^{146}$.

Al margen de su carácter marcadamente religioso, la caridad podía servir como instrumento en manos del donador con otras finalidades, menoscabando en parte el concepto de este tipo de liberalidades. Además de utilizarse como instrumento para adquirir prestigio social, las prácticas caritativas también podían responder a la expiación de una falta moral: «¡Ojalá no hubieses fornicado y no tuvieses que dar limosna!» ${ }^{147}$. La literatura paremiológica guarda silencio en relación con otras motivaciones para practicar la caridad, que no eran eminentemente altruistas, de las cuales sí nos informa la literatura biográfica andalusí ${ }^{148}$.

139 Ibídem, n. ${ }^{\circ} 280$

140 Ibídem, n. ${ }^{\circ} 73$.

141 Sobre la ausencia de una política oficial sistemática para paliar los efectos de la miseria en al-Andalus, cfr. Carballeira, "Pobres y caridad en al-Andalus", 77-78 y 87-88.

142 García Gómez, "Ibn 'Āṣim”, n. ${ }^{\circ} 43$.

143 Ibídem, n. ${ }^{\circ} 121$.

144 Ibídem, n. 275.

145 Corriente y Bouzineb, Alonso del Castillo, n. ${ }^{\circ} 1021$.

146 Ould Mohamed Baba, al-Zajjali, n. ${ }^{\circ} 1942$.

147 García Gómez, "Ibn Hišām”, n. ${ }^{\text {’ }} 10$.

148 Para una información pormenorizada sobre las limosnas que albergaban una se-

Al-Qanțara (AQ) XXVII 1, enero-junio 2006, pp. 105-135 ISSN 0211-3589 
Finalmente, es preciso traer a colación el importante papel desempeñado por la caridad como elemento integrador y estabilizador, ya que ésta podía llegar a tener un efecto positivo en las relaciones sociales. Cuando los poderosos ofrecían amparo a los humildes, aquéllos no sólo sacaban provecho justificando su lugar en la sociedad como protectores de los más desvalidos, sino que también reducían tensión social: «Con la generosidad se tapan los defectos y se concilian los corazones» ${ }^{149}$, «Que no pase el lobo hambre y el pastor no será agraviado» ${ }^{150}$. Si bien la existencia de una jerarquía refuerza el concepto de desigualdad social, no se debe soslayar su importancia en el establecimiento de un equilibrio. Ésta es la razón por la cual, en el marco de una estructura basada en la solidaridad social, se propugna la disparidad: «El exceso de equidad es sospechoso» ${ }^{151}$. Desde esta perspectiva, los conceptos de desigualdad y equilibrio social se hallaban intrínsecamente relacionados.

\section{Conclusiones}

La literatura paremiológica proporciona un caudal de información nada desdeñable en relación con el tema de la pobreza en al-Andalus. El refranero pone a nuestra disposición una serie de imágenes establecidas con respecto a los pobres y a su estado, permitiéndonos conocer los estímulos que esta realidad social provocaba entre la población. En general, al tratarse de un tipo de literatura popular, los proverbios transmiten una percepción más crítica de los pobres en ellos representados que la registrada en otras fuentes documentales. Asimismo, el material recopilado a este respecto confirma algunos aspectos contenidos en otro tipo de textos y amplía ciertas perspectivas con el aporte de nuevos datos.

gunda intención por parte del donante, cfr. Carballeira, "Pobres y caridad en al-Andalus", 80-81.

149 García Gómez, "Ibn 'Āșim”, n. ㅇ 30. En trabajos anteriores ya me he referido a la función desempeñada por la caridad en relación con la integración del pobre en el seno de la sociedad islámica, al ser concebida en parte como una responsabilidad social; cfr. Carballeira, "Pauvreté et fondations pieuses", 415; Idem, "Pobres y caridad en al-Andalus", $84-85$ y 89 .

${ }^{150}$ Ould Mohamed Baba, al-Zajjali, n. ${ }^{\circ} 1998$.

151 Ibídem, n. ${ }^{\circ} 1077$.

Al-Qanțara (AQ) XXVII 1, enero-junio 2006, pp. 105-135 ISSN 0211-3589 
Los refranes andalusíes describen los defectos y las virtudes inherentes al estado de indigencia. La mayor parte de las expresiones analizadas refleja una concepción negativa de la pobreza. En contrapartida, las escasas imágenes positivas de la indigencia advierten de los peligros que emanan de la riqueza material en detrimento de las virtudes morales. En este sentido, frente a refranes localistas, concretos, anecdóticos y pintorescos, otros proverbios son generales, abstractos, moralizantes, pues contienen un discurso ético que proporciona una serie de normas de educación.

Las expresiones analizadas a lo largo de este trabajo hacen referencia a diversos aspectos relativos a los pobres e indigentes en el seno de la sociedad andalusí. Por una parte, destacan las escasas referencias a la pobreza voluntaria por contraposición al significativo predominio de las noticias relativas a la privación involuntaria. Este aspecto quizás haya que ponerlo en conexión con el hecho de que esta última era objeto de constante preocupación en la vida cotidiana de la población andalusí, debido a los múltiples factores susceptibles de generarla y a sus temibles efectos. Desde este punto de vista, los refranes son especialmente prolijos en lo que respecta a las causas y consecuencias de la pobreza. Por una parte, ésta podía venir dada tanto por fenómenos externos como por circunstancias de índole personal. Por otro lado, sus devastadoras consecuencias se traducían principalmente en el padecimiento de privaciones materiales, así como en el menoscabo de la reputación de los afectados, poniendo en entredicho la integridad física y moral de un individuo.

La vulnerabilidad que padecían estos individuos los hacía especialmente propensos a ser objeto de rechazo y marginación por parte de sus correligionarios. Esta circunstancia justifica la existencia de pobres vergonzantes y, junto al temor a las carencias materiales, explica el desvelo existente en prevenir y neutralizar los efectos derivados de la miseria. La literatura paremiológica andalusí es particularmente ilustrativa de las medidas más o menos drásticas con las que los afectados afrontaban su situación de indigencia, si bien algunas de ellas eran un tanto cuestionables desde el punto de vista ético y moral. En general, se recomienda actuar con una buena dosis de pragmatismo, por lo que son constantes las incitaciones a la capacidad de iniciativa, al ahorro y al recurso al propio trabajo. En este contexto, no son menos significativas las noticias relativas a la mendicidad.

Al-Qanțara (AQ) XXVII 1, enero-junio 2006, pp. 105-135 ISSN 0211-3589 
Asimismo, se registran actitudes compasivas y solidarias hacia los más desfavorecidos. Al igual que otro tipo de fuentes, los refranes contienen indicios de que la población andalusí era proclive a los actos caritativos para intentar mitigar las penalidades de los indigentes. Es preciso insertar este tipo de liberalidades en el marco de las exhortaciones contenidas en el Corán para asegurarse la salvación eterna. Sin embargo, este carácter preceptivo quedaba en entredicho cuando la generosidad albergaba una segunda intención por parte del benefactor. En cualquier caso, la incitación a la caridad revela que ésta se concebía como un deber individual, respondiendo a la ausencia de una política oficial sistemática de servicios sociales.

Entre los receptores de caridad se hallan diversas categorías de pobres. Es especialmente relevante la información proporcionada por el refranero en relación con huérfanos y viudas. Tampoco pasan desapercibidas las dificultades económicas de quienes ejercían determinados oficios y de quienes padecían una incapacidad física permanente. De forma general, la literatura paremiológica proporciona imágenes de una simplicidad caricaturesca para definir a los diferentes grupos sociales, cristalizando así la idea de pertenencia a un grupo social concreto. Desde esta perspectiva, el refranero andalusí contiene una cierta regulación social, ya que asigna a cada persona su lugar en el seno de la sociedad, acentuando de este modo las diferencias sociales. En realidad, la desigualdad se considera un estado inherente al orden jerárquico social. Esta tendencia es contrarrestada por la existencia de algunos indicios relativos a la integración de los pobres, lo que contribuye a fomentar el indispensable equilibrio en el marco social.

Resulta poco factible intentar calibrar el uso real del refrán en al-Andalus. La literatura paremiológica andalusí arroja luz sobre algunas expresiones que perviven a lo largo del tiempo sin sufrir apenas alteraciones, lo cual es un claro indicio de que ciertos estereotipos relativos a los pobres e indigentes se han perpetuado en el marco cronológico. Otros proverbios son característicos de determinadas zonas geográficas, siendo reveladores de una mentalidad concreta, relacionada con costumbres locales o con algún hecho particular. Sin embargo, en ciertos casos, las variadas e imprevisibles reacciones del ser humano dan lugar a refranes contradictorios, que presentan un sentido radicalmente opuesto entre sí. En lo que respecta al análisis de este tipo de documentación, es preciso reconocer que, en general, se echan en falta referencias contextuales que completen la información extre- 
madamente concisa y escueta de las fórmulas proverbiales en torno al concepto de pobreza. Por esta razón, es preciso advertir que, aunque en este estudio se efectúe una determinada interpretación del discurso proverbial, no debe soslayarse el hecho de que otras orientaciones de investigación podrían dar lugar a nuevas lecturas e interpretaciones. 